\title{
Editorial Comment: Larger patients shouldn't have fewer options: urethroplasty is safe in the obese
}

\author{
Luciano A. Favorito ${ }^{1}$ \\ ${ }^{1}$ Unidade de Pesquisa Urogenital, Universidade do Estado do Rio de Janeiro, Uerj, RJ, Brasil
}

\section{COMMENT}

The present paper of Alger and colls (1) is very interesting and shows a very important topic in reconstructive urology: The impact of obesity in urethroplasty outcumes. Urethral surgery has more technical difficult in patients with high body mass index (BMI) (2). There are very factors implied in postoperative success of urethral surgery (3-5) but the BMI is one of the most studied (6). In this elegant paper the authors reviewed 193 patients with anterior urethral strictures who had undergone anastomotic or augmentation urethroplasty with at least 12 months follow-up and shows that despite the association with increased urethral stricture length and estimated blood loss, obesity is not predictive of adverse perioperative outcomes or stricture recurrence. Obese patients should be offered urethral reconstruction, but patient selection and preoperative counseling remain imperative.

\section{REFERENCES}

1. Alger J, Wright HC IV, Desale S, Venkatesan K. Larger patients shouldn't have fewer options: urethroplasty is safe in the obese. Int Braz J Urol. 2020;46:962-70.

2. Favorito LA, Conte PP, Sobrinho UG, Martins RG, Accioly T. Double inlay plus ventral onlay buccal mucosa graft for simultaneous penile and bulbar urethral stricture. Int Braz J Urol. 2018;44:838-839.

3. Topakta R, Ürkmez A, Tokuç E, Akyüz M, Kutluhan MA. Hematologic parameters and neutrophil / lymphocyte ratio in the prediction of urethroplasty success. Int Braz J Urol. 2019;45:369-75.

4. Kumar M, Aggarwal A, Pandey S, Agarwal S, Sankhwar SN. Assessment of long term outcomes after buccal mucosal graft urethroplasty: the impact of chronic kidney disease. Int Braz J Urol. 2019;45:981-8.

5. Chapman D, Kinnaird A, Rourke K. Independent Predictors of Stricture Recurrence Following Urethroplasty for Isolated Bulbar Urethral Strictures. J Urol. 2017;198:1107-12.

6. Rapp DE, Mills JT, Smith-Harrison LI, Smith RP, Costabile RA. Effect of body mass index on recurrence following urethroplasty. Transl Androl Urol. 2018;7:673-7.

\section{CONFLICT OF INTEREST}

None declared.

Luciano A. Favorito, MD, PhD

Unidade de Pesquisa Urogenital da Universidade do Estado de Rio de Janeiro - UERJ, Rio de Janeiro, RJ, Brasil E-mail: lufavorito@yahoo.com.br

ARTICLE INFO

Luciano A. Favorito http://orcid.org/0000-0003-1562-6068

Int Braz J Urol. 2020; 46: 971

Submitted for publication: July 01,2020

Accepted: July 30, 2020 